\title{
Effects of level of nutrient intake and age on mammalian target of rapamycin, insulin, and insulin-like growth factor-1 gene network expression in skeletal muscle of young Holstein calves
}

\author{
P. Wang, ${ }^{\star} \dagger$ J. K. Drackley, $\dagger$ J. A. Stamey-Lanier, $\dagger^{1}$ D. Keisler, $\ddagger$ and J. J. Loor ${ }^{2}$ \\ ${ }^{*}$ College of Animal Science and Technology, Northwest A\&F University, Yangling, 712100, China \\ †Department of Animal Sciences and Division of Nutritional Sciences, University of Illinois, Urbana 61801 \\ $\ddagger$ Department of Animal Sciences, University of Missouri, Columbia 65211
}

\begin{abstract}
The molecular mechanisms by which level of nutrient intake enhances skeletal muscle growth in young ruminants are not fully understood. We examined mammalian target of rapamycin (mTOR), insulin, and insulinlike growth factor-1 $(I G F-1)$ gene network expression in semitendinosus muscle tissue of young male Holstein calves fed a conventional milk replacer plus conventional starter $(\mathrm{CON})$ or an enhanced milk replacer plus high-protein starter (ENH) for 5 wk followed by a conventional starter or a high-protein starter until 10 wk of age. Feeding ENH led to greater concentration of plasma IGF-1 and leptin and greater carcass protein and fat mass throughout the study. Despite the greater plasma IGF-1 and protein mass at wk 5, calves fed ENH had lower expression of IGF1R, INSR, and RPS6KB1 but greater expression of IRS1 and PDPK1 in muscle tissue. Except for IGF1R expression, which did not differ at wk 10, these differences persisted at wk 10, suggesting a long-term effect of greater nutrient intake on physiological and molecular mechanisms. Components of mTOR complex (mTORC)1 and mTORC2 (RICTOR and RPTOR) and FOXO1 expression decreased by wk 10 regardless of diet. Overall, the present data revealed that greater nutrient intake throughout the milk-fed and early postweaning phase alters body mass composition partly by altering hormonal and molecular profiles of genes associated with glucose and amino acid signaling. Those networks may play a crucial role in coordinating neonatal muscle growth and metabolism in response to level of nutrient intake.
\end{abstract}

Key words: growth, metabolism, dairy calf, protein synthesis

Received May 17, 2013.

Accepted September 15, 2013.

${ }^{1}$ Current address: Prince Agri Products Inc., 229 Radio Road, Quincy, IL 62306.

${ }^{2}$ Corresponding author: jloor@illinois.edu

\section{INTRODUCTION}

Physiological and molecular studies primarily in nonruminants have provided evidence of higher growth rates in neonates attributed to the feeding-induced stimulation of protein synthesis in muscle via insulin- and AA-mediated signaling pathways (Davis and Fiorotto, 2009). The mammalian target of rapamycin (mTOR) signaling pathway, which is downstream of insulin and AA signaling, plays a central role in enhancing protein synthesis and cell growth (Wullschleger et al., 2006). Signaling through IGF-1 and the IGF-1 receptor also appears to play a role in skeletal muscle cell differentiation during the neonatal period (Dickson et al., 1991). Furthermore, hypertrophy of skeletal muscle myotubes is enhanced through the activation of the IGF-1-mTOR signaling pathways (Rommel et al., 2001).

Dietary protein ingestion affects the expression of growth hormone receptor $(G H R)$ or IGF1 in muscle (Brameld et al., 1996), and the concentration of both hormones in blood (Daniels et al., 2009). Therefore, the greater growth rate of dairy calves (Blome et al., 2003; Bartlett et al., 2006) fed higher-protein diets could involve not only hormonal changes but also alterations in mRNA expression of genes associated with mTOR, insulin, and IGF-1 signaling pathways. From a nutritional standpoint, however, alterations in expression of the negative feedback loop encompassing tuberous sclerosis 2 (TSC2)-mTOR-ribosome protein S6 kinase (RPS6KB1)-insulin receptor substrate 1 (IRS1) (Harrington et al., 2004; Um et al., 2006; Tremblay et al., 2007) are important. In humans, nutrient overload or obesity leads to altered insulin sensitivity (Um et al., 2006), with potential involvement of this feedback loop in coordinating such a response. Relatively little is known in livestock species about the expression pattern of mTOR, insulin, and IGF-1 signaling pathways and the feedback loop as it relates to level of nutrient intake and physiological state. Therefore, it is important to understand the molecular events whereby diet coordinates growth and metabolism. 


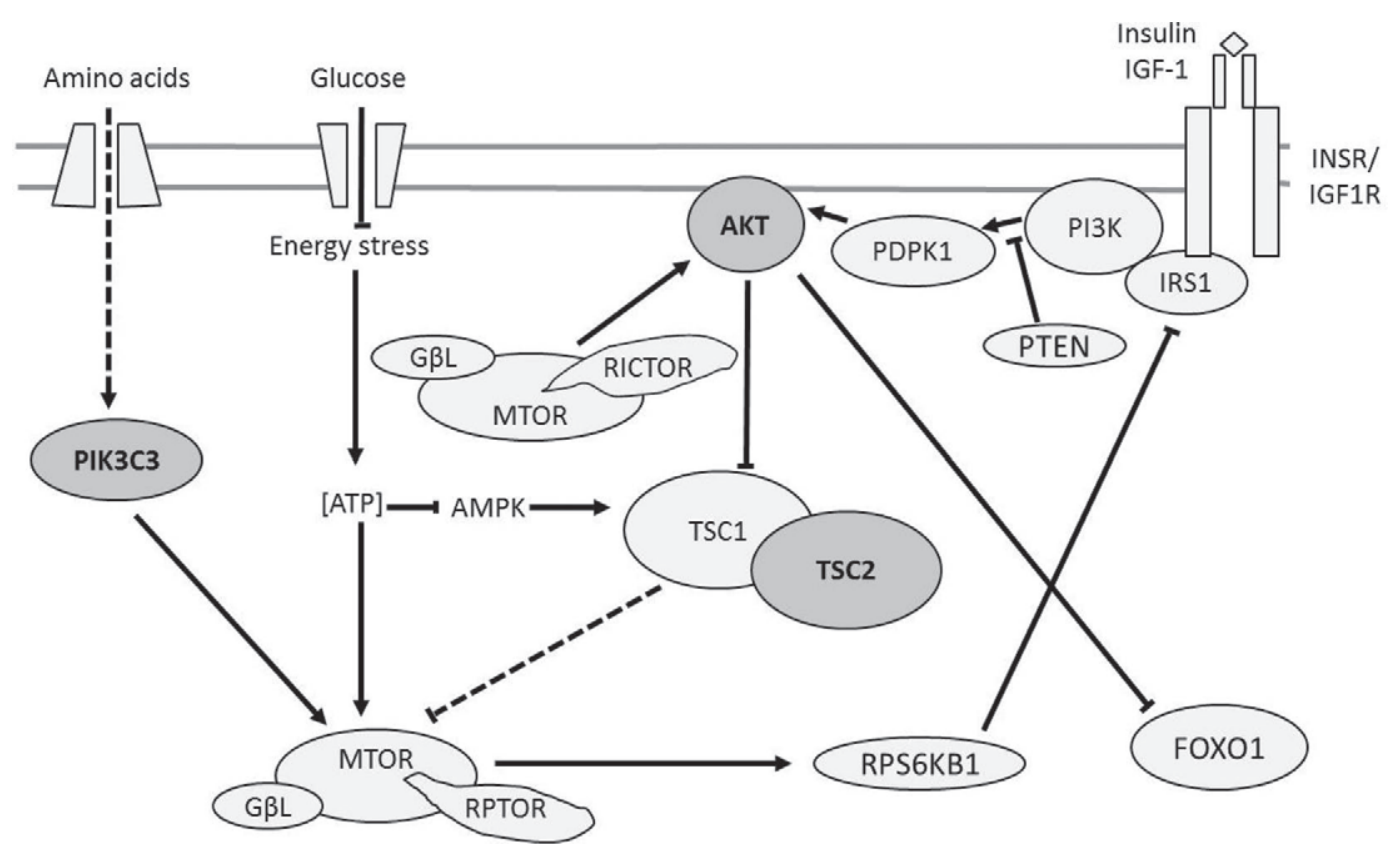

Figure 1. Model depicting the mammalian target of rapamycin (mTOR) signaling pathway in response to nutrients and growth factors. The mTOR complex (mTORC)1, including mTOR, regulatory-associated proteins of mTOR (RPTOR), and G protein $\beta$-subunit-like protein (GßL), plays central roles in modulating cell growth and metabolism in response to extracellular growth stimuli, including nutritional signals (amino acids and glucose) and growth factors. On one hand, the mTOR pathway responds to growth factors via the phosphatidylinositol 3-kinase/protein kinase B (PI3K/Akt) pathway. Binding of insulin or IGF to their receptor (i.e., INSR or IGF1R) leads to recruitment and phosphorylation of insulin receptor substrate 1 (IRS-1) and subsequent recruitment of PI3K, and PI3K bound to IRS coverts phosphatidylinositol-4,5-phosphate (PIP2) in the cell membrane to phosphatidylinositol-3,4,5-phosphate (PIP3). Accumulation of PIP3 is antagonized by the lipid phosphatase phosphatase and tensin homolog (PTEN). PIP3 co-recruits PDK1 and Akt to the membrane, resulting in the phosphorylation and activation of Akt by PDK1. mTOR is wired to the PI3K pathway through tuberous sclerosis complex (TSC)1/TSC2 (Wullschleger et al., 2006). The TSC1/ TSC2 complex acts as a negative modulator of mTORC1 relaying growth factors signals in addition to energy status. Energy stress conditions leads to activation of AMP-activated protein kinase (AMPK), which phosphorylates TSC2 (Inoki et al., 2003). The TSC1/TSC2 complex is also required for maintaining insulin signaling to PI3K by repressing a negative feedback loop from mTOR/S6K (also known as ribosomal protein S6 kinase beta-1, RPS6KB1) to the adaptor molecule IRS-1 (Harrington et al., 2004). On the other hand, AA seem to be the most crucial signals for mTORC1 activation (see review by Jewell and Guan, 2013). Nutrients such as AA and glucose increases hVps 34 (also known as phosphatidylinositol 3-kinase, catalytic subunit type 3, PIK3C3) activity, stimulating the production of PI3P; PI3P, in turn, recruits proteins containing FYVE or PX domains to endosomal membranes (see review by Um et al., 2006). Additionally, Akt seems to play a pivotal role in the regulation of skeletal muscle hypertrophy and atrophy in rodents and cells through mTOR and FOXO1 (Léger et al., 2006). Moreover, Akt is suggested to be a downstream of mTORC2, which contains mTOR, rapamycin-insensitive companion of mTOR (RICTOR), and GßL (Sarbassov et al., 2005).

Components of cell growth and metabolism related to the mTOR, insulin, and IGF-1 signaling pathways that were measured in this study are shown in Figure 1. The figure was developed primarily based on the review of Wullschleger et al. (2006). The main objective of this study was to examine the effect of level of nutrient intake (Naeem et al., 2012; Stamey et al., 2012) on expression of genes with relevance to the mTOR, insulin, and IGF-1 signaling pathways in skeletal muscle. Our general hypothesis was that both plane of nutrition and stage of growth would alter mRNA expression of genes associated with these pathways. Quantitative PCR (qPCR) was used as a tool for in-depth study of the relationships among the 15 genes chosen and hormones in response to different plane of nutrition from birth through the first week after weaning. The present data provide evidence of coordination between growth and metabolism when different levels of nutrition are provided to young calves.

\section{MATERIALS AND METHODS}

\section{Experimental Animals and Sampling}

Details of diets and general management have been published (Stamey et al., 2012). Briefly, male calves were fed 1 of 2 different diets: (1) control (CON), conventional milk replacer (MR; $20 \% \mathrm{CP}, 20 \%$ fat, 4.95 Mcal $/ \mathrm{kg}$ of DM) plus conventional starter (19.6\% CP, $3.16 \mathrm{Mcal} / \mathrm{kg}$ of DM); and (2) enhanced (ENH) MR (28.5\% CP, $15 \%$ fat, $4.72 \mathrm{Mcal} / \mathrm{kg}$ of DM) plus high-CP starter $(25.5 \% \mathrm{CP}, 3.21 \mathrm{Mcal} / \mathrm{kg}$ of DM). Conventional MR was reconstituted to $12.5 \%$ solids and fed at $1.25 \%$ of birth BW daily in 2 feedings from wk 1 to 5 and at 
$0.625 \%$ of birth BW once daily during wk 6 . Enhanced MR was reconstituted to $15 \%$ solids and fed at $1.5 \%$ of $\mathrm{BW}$ during wk 1 , and at $2 \%$ of $\mathrm{BW}$ during wk 2 to 5 , divided into 2 daily feedings. Calves were offered starter for ad libitum intake starting on d 3. Calf starter intake was recorded once daily. After weaning (wk 7 through 10), calves in CON and ENH continued to receive the respective starter ad libitum.

Animals used in the present study came from a previous larger study (Stamey, 2008). Details of measurement and analysis of animal performance (i.e., ADG, carcass weight, carcass composition, empty BW, composition of empty BW) are reported elsewhere (Stamey, 2008; Naeem et al., 2012; Stamey et al., 2012). Five calves from each treatment were slaughtered at $43 \mathrm{~d}$ (wk 5) and 5 were slaughtered at $71 \mathrm{~d}$ (wk 10) of life at the Meat Sciences Laboratory at the University of Illinois, Urbana-Champaign, via captive bolt stunning followed by exsanguination. Calves slaughtered at 10 wk of age had been weaned at d 42. Semitendinosus muscle samples $(\sim 0.5 \mathrm{~g})$ from a rear leg were collected and stored in liquid $\mathrm{N}_{2}$ until RNA extraction.

Blood was collected each Monday at $0500 \mathrm{~h}$, before the morning feeding, via jugular venipuncture. Samples were collected into evacuated serum tubes (SST serum separator tube; Becton Dickinson Vacutainer Systems, Franklin Lakes, NJ) containing clot activator. Serum was obtained by centrifugation at $1,300 \times g$ for $15 \mathrm{~min}$. The serum and plasma recovered were aliquoted into polypropylene tubes and frozen $\left(-20^{\circ} \mathrm{C}\right)$ until analyses. Concentrations of growth hormone (GH), IGF-1, and leptin were measured via RIA as described previously (Powell and Keisler, 1995; Lalman et al., 2000).

\section{RNA Extraction, Real-Time Reverse Transcription- $P C R$, and Primer Design and Evaluation}

The complete details of these procedures can be found in the supplemental file (http://dx.doi.org/10.3168/ jds.2013-7042). Briefly, semitendinosus tissue was weighed $(\sim 0.3-0.5 \mathrm{~g})$ and immediately subjected to RNA extraction with ice-cold Trizol (Invitrogen Corp., Carlsbad, CA) as described previously (Graugnard et al., 2009). The quality of RNA was assessed using a 2100 Bioanalyzer (Agilent Technologies, Santa Clara, $\mathrm{CA}$ ). The average RNA integrity number of the samples used was $>8.0$. A portion of the RNA was diluted to $100 \mathrm{mg} / \mathrm{L}$ using DNase-, RNase-free water before reverse transcription.

The cDNA were synthesized using 100 ng of RNA, 1 $\mu \mathrm{g}$ of dT18 (Operon Biotechnologies, Huntsville, AL), 1 $\mu \mathrm{L}$ of $10 \mathrm{mmol} / \mathrm{L}$ dNTP mix (Invitrogen Corp.), $1 \mu \mathrm{L}$ of random primer $\mathrm{p}(\mathrm{dN})_{6}$ (Roche cat. no. 11034731 001; Roche, Indianapolis, IN), and $10 \mu \mathrm{L}$ of DNase-,
RNase-free water. The qPCR was performed using 4 $\mu \mathrm{L}$ of diluted cDNA (dilution 1:4) combined with $6 \mu \mathrm{L}$ of a mixture composed of $5 \mu \mathrm{L}$ of $1 \times \mathrm{SYBR}$ Green master mix (Applied Biosystems, Foster City, CA), 0.4 $\mu \mathrm{L}$ each of $10 \mu M$ forward and reverse primers, and $0.2 \mu \mathrm{L}$ of DNase-, RNase-free water in a MicroAmp Optical 384-Well Reaction Plate (Applied Biosystems). Each sample was run in triplicate and a 6-point relative standard curve plus the nontemplate control were used (User Bulletin \#2, Applied Biosystems). The cycle threshold $(\mathrm{Ct})$ data were analyzed and transformed using the 7900 HT Sequence Detection Systems Software (version 2.2.1, Applied Biosystems). The final data were normalized using the geometric mean of the 4 moststable genes among the ones tested as internal controls, and the percentage of specific mRNA abundance among total mRNA from all genes quantified in present study was calculated as reported previously (Bionaz and Loor, 2007). This approach is particularly helpful for the biological interpretation of the change in expression of genes as it relates to the relative amount of mRNA in the biological sample. Sequence information of primers for the target genes of interest is listed in Supplemental Table S1 (http://dx.doi.org/10.3168/jds.2013-7042).

\section{Selection and Evaluation of Internal Control Genes}

The geometric mean of actin- $\beta$ (ACTB), ELKS/ RAB6-interacting/CAST family member 1 (ERC1), mitochondrial ribosomal protein L39 (MRPL39), and ubiquitously expressed transcript $(U X T)$ was used to normalize gene expression data (Supplemental Figures S1 and S2; http://dx.doi.org/10.3168/jds.2013-7042).

\section{Statistical Analysis}

Data were analyzed using Proc MIXED in SAS as a repeated-measures ANOVA (SAS Institute Inc., Cary, $\mathrm{NC})$. The qPCR data normalized with the internal control genes (ICG) were log-2 transformed before statistical analysis. The model consisted of diet, age, and the diet $\times$ age interaction as fixed effects, as well as calf nested within diet $\times$ age as a random effect. An autoregressive covariance structure was used. Least squares means were computed and were compared using the PDIFF statement of SAS (SAS Institute Inc.). Significance was declared at $P \leq 0.10$.

\section{RESULTS}

\section{Animal Performance}

Calves fed ENH had greater $(P<0.05)$ final live BW, ADG, preharvest shrunk BW (SBW), and car- 
cass weight (Table 1$)$. Carcass as a percentage of SBW was not affected $(P=15)$ by diet but was less $(P<$ $0.05)$ in calves at $10 \mathrm{wk}$ than in those at $5 \mathrm{wk}$. Calves fed ENH had greater $(P<0.05)$ liver weight than those fed CON, and liver was heavier $(P<0.05)$ at $10 \mathrm{wk}$ than at $5 \mathrm{wk}$. As a percentage of SBW, however, liver weight did not differ $(P=0.17)$ between diets but was greater $(P<0.05)$ at 10 wk than at 5 wk. Calves fed ENH had greater amounts of protein $(P<0.01)$, fat $(P=0.10)$, and ash $(P<0.01)$ in the carcass because of larger carcass mass, but percentages of protein, fat, and ash did not vary between diets. The percentage of fat in the carcass of 10 -wk-old calves was greater than that in calves at $5 \mathrm{wk}$.

\section{Concentrations of Hormones in Blood}

An overall diet effect was observed for growth hormone $(P=0.02)$, IGF-1 $(P<0.01)$, and leptin $(P=$ $0.08)$, with higher concentrations observed in calves fed ENH (Table 1$)$. The concentration of GH $(P<0.01)$ and leptin $(P<0.06)$ was lower at wk 10 than at wk 5 regardless of diet.

\section{Gene Expression}

Among the genes measured, v-akt murine thymoma viral oncogene homolog 1 (AKT1), phosphoinositide- 3-kinase (PIK3C3), regulatory associated protein of mTOR (RPTOR), and TSC2 had the greatest relative mRNA abundance and accounted for 12.4, 18.6, 11.9, and $18.8 \%$ among all mRNA quantified in present study, respectively (Table 2 ). We detected a diet $\times$ age $(P=0.04)$ interaction for $I G F 1 R$ expression due to lower expression for calves fed ENH compared with $\mathrm{CON}$ at wk 5. A diet $\times$ age interaction was observed for TSC2 $(P=0.02)$ due to higher expression of TSC2 in calves fed ENH compared with CON at wk 10 or ENH at wk 5, whereas the opposite pattern of expression observed for tuberous sclerosis 1 (TSC1) reflected downregulated expression $(P=0.10)$ in calves fed ENH at wk 10 compared with wk 5 .

Overall diet effects were observed for IRS1 $(P=$ $0.02)$, RPS6KB1 $(P=0.03)$, insulin receptor (INSR, $P=0.10)$ and 3 -phosphoinositide-dependent protein kinase $(P D P K 1, P=0.10)$. Insulin receptor substrate 1 and INSR were downregulated, and RPS6KB1 and $P D P K 1$ were upregulated in response to feeding ENH compared with CON. An overall age effect was observed for forkhead box O1 (FOXO1, P = 0.04), INSR $(P=0.05)$, RPTOR independent companion of mTOR, complex 2 (RICTOR, $P=0.07)$, and RPTOR $(P=$ $0.10)$, all of which decreased in expression at wk 10 compared with wk 5.

Table 1. Carcass composition and hormones in blood of male Holstein calves fed a conventional milk replacer (20\% CP, $20 \%$ fat) plus conventional starter (CON; $19.6 \% \mathrm{CP}$ ) or enhanced milk replacer $(28.5 \% \mathrm{CP}, 15 \%$ fat) plus high-CP starter (ENH; $25.5 \% \mathrm{CP})$ from d 3 to wk 6 of age followed by a 4 -wk period of feeding a conventional starter $(\mathrm{CON})$ or high-CP starter $(\mathrm{ENH})$

\begin{tabular}{|c|c|c|c|c|c|c|c|c|}
\hline Item & \multicolumn{2}{|c|}{ Wk 5} & \multicolumn{2}{|c|}{ Wk 10} & $\mathrm{SEM}^{1}$ & \multicolumn{3}{|c|}{$P$-value ${ }^{2}$} \\
\hline Final live BW, $\mathrm{kg}$ & 59.4 & 72.9 & 85.5 & 109.8 & 7.9 & 0.02 & 0.001 & 0.47 \\
\hline Preharvest shrunk BW (SBW), kg & 57.1 & 71.0 & 81.3 & 106.4 & 7.4 & 0.01 & 0.001 & 0.43 \\
\hline Carcass weight, $\mathrm{kg}$ & 33.5 & 42.9 & 42.2 & 56.0 & 4.1 & 0.01 & 0.01 & 0.57 \\
\hline Carcass, $\%$ of SBW & 58.7 & 60.4 & 51.7 & 52.7 & 0.9 & 0.15 & 0.001 & 0.67 \\
\hline \multicolumn{9}{|l|}{ Carcass composition } \\
\hline Protein, kg & 5.87 & 7.51 & 7.37 & 10.1 & 0.81 & 0.01 & 0.01 & 0.46 \\
\hline Fat, $\mathrm{kg}$ & 1.64 & 2.18 & 2.72 & 3.63 & 0.45 & 0.10 & 0.01 & 0.65 \\
\hline Ash, kg & 1.54 & 1.89 & 1.90 & 2.45 & 0.19 & 0.01 & 0.01 & 0.57 \\
\hline \multicolumn{9}{|l|}{ Carcass composition } \\
\hline Protein, \% & 17.54 & 17.48 & 17.32 & 18.05 & 0.31 & 0.26 & 0.57 & 0.19 \\
\hline Fat, $\%$ & 4.90 & 5.07 & 6.18 & 6.35 & 0.47 & 0.70 & 0.01 & 0.99 \\
\hline \multicolumn{9}{|l|}{ Blood $^{3}$} \\
\hline
\end{tabular}

${ }^{1} \mathrm{SEM}=$ the largest standard error of the mean.

${ }^{2} P$-value for the effect of diet $(\mathrm{D})$, age $(\mathrm{A})$, and $\operatorname{diet} \times$ time $(\mathrm{D} \times \mathrm{A})$.

${ }^{3}$ Concentrations of insulin, glucose, NEFA, total protein, urea-N, and hydroxybutyric acid have been published (Naeem et al., 2012). GH $=$ growth hormone. 
Table 2. Relative mRNA expression (log-2 scale) and the percentage of specific mRNA abundance among the total mRNA of genes quantified in present study in skeletal muscle of male Holstein calves fed a conventional milk replacer $(20 \% \mathrm{CP}, 20 \%$ fat) plus conventional starter (CON; $19.6 \% \mathrm{CP})$ or enhanced milk replacer (28.5\% CP, $15 \%$ fat) plus high-CP starter (ENH; $25.5 \% \mathrm{CP}$ ) from d 3 of age to wk 6 of age followed by a 4-wk period of feeding a conventional starter (CON) or high-CP starter (ENH)

\begin{tabular}{|c|c|c|c|c|c|c|c|c|c|}
\hline \multirow[b]{2}{*}{ Gene (symbol) } & \multirow[b]{2}{*}{$\% \mathrm{mRNA}^{1}$} & \multicolumn{2}{|c|}{ Wk 5} & \multicolumn{2}{|c|}{ Wk 10} & \multirow[b]{2}{*}{$\mathrm{SEM}^{2}$} & \multicolumn{3}{|c|}{$P$-value ${ }^{3}$} \\
\hline & & $\mathrm{CON}$ & ENH & $\mathrm{CON}$ & ENH & & $\mathrm{D}$ & $\mathrm{A}$ & $\mathrm{D} \times \mathrm{A}$ \\
\hline v-akt murine thymoma viral oncogene homolog 1 ( AKT1) & 12.4 & 4.23 & 4.35 & 4.30 & 4.28 & 0.06 & 0.45 & 0.94 & 0.22 \\
\hline Forkhead box O1 (FOXO1) & 4.2 & 5.10 & 4.82 & 4.21 & 4.39 & 0.35 & 0.87 & 0.04 & 0.47 \\
\hline IGF-1 receptor $(I G F 1 R)$ & 3.5 & $4.83^{*}$ & $4.56^{*}$ & 4.62 & 4.79 & 0.11 & 0.60 & 0.95 & 0.04 \\
\hline Insulin receptor $(I N S R)$ & 7.6 & 5.00 & 4.86 & 4.82 & 4.71 & 0.09 & 0.10 & 0.05 & 0.89 \\
\hline Insulin receptor substrate 1 (IRS1) & 2.7 & 4.82 & 5.15 & 4.73 & 5.03 & 0.14 & 0.02 & 0.45 & 0.90 \\
\hline FKBP12-rapamycin complex-associated protein $(M T O R)$ & 1.9 & 5.11 & 5.04 & 5.07 & 4.93 & 0.09 & 0.23 & 0.39 & 0.72 \\
\hline 3-Phosphoinositide-dependent protein kinase $(P D P K 1)$ & 1.5 & 4.83 & 5.00 & 4.96 & 5.20 & 0.12 & 0.10 & 0.21 & 0.95 \\
\hline Phosphoinositide-3-kinase (PIK3C3) & 18.6 & 5.24 & 5.19 & 5.04 & 5.15 & 0.09 & 0.73 & 0.15 & 0.36 \\
\hline Phosphatase and tensin homolog (PTEN) & 4.2 & 4.73 & 4.94 & 4.99 & 4.97 & 0.11 & 0.36 & 0.15 & 0.27 \\
\hline RPTOR independent companion of mTOR (RICTOR) & 4.6 & 5.08 & 5.02 & 4.95 & 4.79 & 0.11 & 0.27 & 0.07 & 0.63 \\
\hline Ribosomal protein $\mathrm{S} 6$ kinase (RPS6KB1) & 1.5 & 5.06 & 4.82 & 5.09 & 4.94 & 0.10 & 0.03 & 0.41 & 0.65 \\
\hline Regulatory associated protein of mTOR (RPTOR) & 11.9 & 4.79 & 4.87 & 4.61 & 4.77 & 0.09 & 0.19 & 0.10 & 0.69 \\
\hline Ras-related GTP binding $\mathrm{C}(R R A G C)$ & 2.9 & 5.03 & 4.91 & 5.18 & 5.03 & 0.12 & 0.23 & 0.22 & 0.88 \\
\hline Tuberous sclerosis 1 (TSC1) & 3.4 & 4.94 & $5.08^{\mathrm{a}}$ & 4.93 & $4.79^{\mathrm{b}}$ & 0.08 & 0.97 & 0.06 & 0.10 \\
\hline Tuberous sclerosis 2 (TSC2) & 18.8 & 4.69 & $4.55^{\mathrm{b}}$ & $4.77^{*}$ & $4.97^{* \mathrm{a}}$ & 0.08 & 0.74 & 0.01 & 0.02 \\
\hline
\end{tabular}

${ }^{\mathrm{a}, \mathrm{b}}$ Means with different symbols denote significant interactions due to diet $\times$ age $(\mathrm{D} \times \mathrm{A})$ between week $(P \leq 0.10)$

${ }^{1}$ The $\%$ mRNA abundance was calculated as $\left\{\left[\left(1 / \mathrm{E}^{\Delta \mathrm{Ct}}\right)\right.\right.$ specific gene/sum $\left(1 / \mathrm{E}^{\Delta \mathrm{Ct}}\right)$ all genes $\left.] \times 100\right\}$, where $\mathrm{E}=10^{(-1 / \mathrm{Curve} \text { Slope })}$, and $\Delta \mathrm{Ct}=\mathrm{Ct}$ gene - geometric mean $\mathrm{Ct}$ of 4 internal control genes.

${ }^{2} \mathrm{SEM}$ is the largest standard error of the mean.

${ }^{3} P$-value for the effect of $\operatorname{diet}(\mathrm{D})$, age $(\mathrm{A})$, and $\operatorname{diet} \times$ age $(\mathrm{D} \times \mathrm{A})$.

O $*$ Means with symbols differ due to diet $\times$ age $(\mathrm{D} \times \mathrm{A})$ within week $(P \leq 0.10)$. 


\section{DISCUSSION}

\section{Gene Markers of Protein Metabolism in Skeletal Muscle}

Physiological studies in piglets have demonstrated that the enhanced rate of protein synthesis induced by greater diet consumption is an effect of elevated postprandial signals such as insulin and AA (Davis et al., 2010). Similar effects on protein synthesis in muscle were also observed in hind-limb of sheep (Oddy et al., 1987; Wester et al., 2000) and rats (Garlick et al., 1983). Those responses to feeding, however, decreased with age in piglets (Davis et al., 1996) and horses (Wagner and Urschel, 2012). Molecular events, including the components involved in insulin and AA signaling pathways, as well as the mTOR signaling pathway, have provided evidence to support the above physiological effects (Davis and Fiorotto, 2009).

In the present study, downregulation of INSR at wk 10 compared with wk 5 , combined with the downregulation of components of mTOR complex (mTORC) 1 and mTORC2 (i.e., RICTOR and RPTOR), which are implicated in the regulation of cell growth (Wullschleger et al., 2006), suggests a decrease in the rate of protein synthesis via insulin and AA signaling. The pattern of transcriptional alterations in skeletal muscle with age in the present study agrees with observations from a series of studies in neonatal pig muscle (Suryawan and Davis, 2003, 2005, 2010; Suryawan et al., 2001, 2004, 2006, 2007). Those studies reported that enhanced protein synthesis was paralleled by an activation of the insulin signaling cascade, including INSR, IRS-1/2, phosphatidylinositol 3-kinase (PI3K), PDPK1, and protein kinase B (PKB or AKT).

We cannot rule out the possibility, however, that AA availability mediates cell growth through activation of mTOR. For instance, it has been reported that AA are important regulators of mTORC1 activation and enhanced cell growth, a process suggested to occur in a class III PI3K (hVps34)-dependent manner (Nobukuni et al., 2005; Yoon et al., 2011). Moreover, AA may activate $\mathrm{mTORC} 2$ in a different way from their effect on mTORC1; for example, via activity of class I PI3K and of AKT, which is dependent on the presence of RICTOR, a specific component of mTORC2 (Tato et al., 2011). The selective activation of mTORC1 or mTORC2 by AA can occur under different starvation conditions (Tato et al., 2011). For instance, in overnight serum-starved cells, AA induced the phosphorylation of Akt through class I PI3K and mTORC2 (Tato et al., 2011). On the other hand, when the culture medium was devoid of AA, the stimulation of RPS6KA1, S6 ribosomal protein (RPS6), and eIF4E binding protein
1 (4E-BP1) was inhibited by rapamycin, wortmannin, and the hVps34 inhibitor 3-methyladenine. Those results suggested that the effect of AA is mediated by the class III PI3K hVps34 and mTORC1 (Tato et al., 2011). Together with the high abundance of PIK3C3, $A K T 1$, and RPTOR in skeletal muscle, the lower expression of RPTOR and RICTOR at wk 10 in our study suggests a developmentally reduced sensitivity of skeletal muscle to AA. Because of the complexity of mTORC1 and mTORC2 regulation, more studies are needed to improve our understanding of the role of AA in mTOR activation in young calves.

The downregulated expression of FOXO1 coupled with the lack of change in expression of $A K T 1$ at wk 10 of age (Table 2) could be taken as an indication that protein degradation may have decreased during growth. Activation of AKT1 regulates both hypertrophy and atrophy through its effect on FOXO1 and mTOR (Léger et al., 2006). Phosphorylation of FOXO1 by AKT1 activates ubiquitin-protein ligases and leads to skeletal muscle atrophy (Stitt et al., 2004; Glass, 2010). In vitro, it has been shown that activation of FOXO1 in murine myoblasts blocked myogenic differentiation and led to proteasomal degradation of mTOR, RPTOR, TSC2, and RPS6KB1 (Wu et al., 2008).

\section{Gene Markers of Insulin Sensitivity in Skeletal Muscle}

Previous work has underscored a critical role for the activation of RPS6KB1-IRS1signaling in compensating for a decline in sensitivity to insulin during metabolic abnormalities such as obesity and type II diabetes (Tremblay et al., 2005; Um et al., 2006). Increased insulin sensitivity was observed in $R P S 6 K B 1^{-/-}$mice on a high-fat diet compared with wild-type mice, suggesting that the absence of RPS6KB1 facilitates insulin signaling (Um et al., 2004). In the present study, the upregulation of IRS1 and PDPK1 in parallel with the downregulation of RPS6KB1 due to feeding ENH would indicate greater insulin sensitivity.

The greater growth rate in calves fed ENH was due to the greater rate of carcass accumulation without changes in chemical composition (Table 1). Taken together with those data, the lower overall INSR expression coupled with a lower glucose-to-insulin ratio in the same calves as previously reported (Naeem et al., 2012), particularly after weaning (0.34 vs. 0.43 for CON and ENH; $P<0.10$; Naeem et al., 2012), might argue against decreased insulin sensitivity for ENH calves after weaning. This agrees with the negative feedback action of TSC2 on insulin sensitivity via regulation of IRS1 (Harrington et al., 2004), which is discussed below. 


\section{Gene Markers of Energy Metabolism in Skeletal Muscle}

The high mRNA abundance of TSC2 among measured genes (and also relative to TSC1) underscores its essential role in integrating energy metabolism and muscle cell growth. The expression and function of TSC2 is regulated by cellular energy level (Inoki et al., 2003). The marked increase of TSC2 expression in ENH compared with CON after weaning seems to suggest a residual effect of the improved nutrient status before weaning on growth. The lower overall expression of $R P$ $S 6 K B 1$ in response to ENH supports this suggestion.

The opposite response in TSC1 and TSC2 expression agrees with the idea that both work in concert to regulate mTOR downstream (Tee et al., 2002). Although as a percentage of $\mathrm{BW}$, it represented only a $0.5 \%$ increase, the greater overall mass of carcass protein at wk 10 in calves fed ENH compared with those fed CON (Table 1) suggests a positive effect of high-quality starter on muscle growth postweaning. Tuberous sclerosis 2, which is regulated by both AMPK and PI3K/Akt (Hay and Sonenberg, 2004), has been proposed as an integrator of insulin and energy status in the processes regulating cell growth.

In human cancers and tumor syndromes (e.g., tuberous sclerosis complex and Peutz-Jegher's syndrome), which are characterized by imbalance of intracellular energy, the lack of TSC2 attenuates insulin sensitivity through a failure of inhibition of RPS6KB1 action on IRS1 (Harrington et al., 2004). Furthermore, AA or glucose stimulated Ser302 phosphorylation of IRS1, which is normally inhibited by wortmannin or rapamycin (Giraud et al., 2004), suggesting a positive role of nutrients (AA and glucose) on insulin signaling via the mTOR cascade.

If one assumes that the weaning transition encompasses a period of nutrient stress (Mieulet and Lamb, 2010), it could be possible that the postweaning increase in carcass mass (without changes in chemical composition) in response to high-quality dietary starter was driven, at least in part, by an improvement of insulin sensitivity via TSC1/2 to maintain normal insulin signaling at the level of PI3K (Harrington et al., 2004). Furthermore, TSC2 upregulation between wk 5 and 10 for calves fed ENH appears to suggest that a high plane of nutrition could curtail any negative effect of age on growth because previous work demonstrated that TSC2 is a negative regulator of mTOR signaling during cell growth (Mieulet and Lamb, 2010).

\section{Gene Markers of Muscle Growth in Young Calves}

Postnatal muscle growth is partly attributed to hypertrophy (Brameld et al., 1998). The IGF-1/IGF-1 receptor signaling pathway, which regulates anabolic processes such as protein synthesis, plays a crucial role in muscle growth of the young animal due to the hypertrophic effects of local IGF-1 (Barton-Davis et al., 1999). The decrease in expression of IGF1R mRNA during postnatal development in the rat (Werner et al., 1989) is suggestive of an involvement of IGF-1 signaling in muscle growth of young animals. Accordingly, the more pronounced effect of ENH on calf growth (i.e., carcass accumulation, Table 1; Naeem et al., 2012) during the milk-fed period was associated with lower IGF1R expression (Table 2), which may be interpreted as a sign of greater protein accumulation due to enhanced hypertrophic effects by the improved plane of nutrition (Brameld et al., 1998). The observed changes in hormones support the benefit of ENH on protein accumulation; that is plasma concentration of IGF-1 reflected plane of nutrition and $\mathrm{GH}$ was inversely related to the plane of nutrition (Chelikani et al., 2009). In those mice, the impaired muscle growth was characterized by a decrease in fiber size, but not by a decrease in fiber number, suggesting that the activation of satellite cells is needed by, and provides structural basis for, the subsequent muscle hypertrophy during growth.

\section{CONCLUSIONS}

Although more molecular and cellular studies are needed, results from this study suggest 2 possible explanations for the adaptation of growth and metabolism due to changes in nutrition level in young calves: (1) enhanced growth in calves fed the ENH milk replacer during the preweaning period contributes to better responses to postweaning high level of nutrition; and (2) better quality of starter has the potential to improve insulin sensitivity due to upregulation of TSC1/TSC2, leading to lower inhibition of RPS6KB1 on IRS1.

\section{ACKNOWLEDGMENTS}

Partial financial support was provided by Hatch funds under project ILLU-538-392 (National Institute of Food and Agriculture, Washington, DC), the Scientific Research Starting Foundation for Doctors of Northwest A\&F University, China (project no. 2012BSJJ086), and the Fundamental Research Funds for the Central Universities, China (project no. QN2013022).

\section{REFERENCES}

Bartlett, K. S., F. K. McKeith, M. J. VandeHaar, G. E. Dahl, and J. K. Drackley. 2006. Growth and body composition of dairy calves fed milk replacers containing different amounts of protein at two feeding rates. J. Anim. Sci. 84:1454-1467. 
Barton-Davis, E. R., D. I. Shoturma, and H. L. Sweeney. 1999. Contribution of satellite cells to IGF-I induced hypertrophy of skeletal muscle. Acta Physiol. Scand. 167:301-305.

Bionaz, M., and J. J. Loor. 2007. Identification of reference genes for quantitative real-time PCR in the bovine mammary gland during the lactation cycle. Physiol. Genomics 29:312-319.

Blome, R. M., J. K. Drackley, F. K. McKeith, M. F. Hutjens, and G. C. McCoy. 2003. Growth, nutrient utilization, and body composition of dairy calves fed milk replacers containing different amounts of protein. J. Anim. Sci. 81:1641-1655.

Brameld, J. M., J. L. Atkinson, J. C. Saunders, J. M. Pell, P. J. Buttery, and R. S. Gilmour. 1996. Effects of growth hormone administration and dietary protein intake on insulin-like growth factor I and growth hormone receptor mRNA Expression in porcine liver, skeletal muscle, and adipose tissue. J. Anim. Sci. 74:1832-1841.

Brameld, J. M., P. J. Buttery, J. M. Dawson, and J. M. Harper. 1998. Nutritional and hormonal control of skeletal-muscle cell growth and differentiation. Proc. Nutr. Soc. 57:207-217.

Chelikani, P. K., D. J. Ambrose, D. H. Keisler, and J. J. Kennelly. 2009. Effects of dietary energy and protein density on plasma concentrations of leptin and metabolic hormones in dairy heifers. J. Dairy Sci. 92:1430-1441.

Daniels, K. M., A. V. Capuco, M. L. McGilliard, R. E. James, and R. M. Akers. 2009. Effects of milk replacer formulation on measures of mammary growth and composition in Holstein heifers. J. Dairy Sci. 92:5937-5950.

Davis, T. A., D. G. Burrin, M. L. Fiorotto, and H. V. Nguyen. 1996 Protein synthesis in skeletal muscle and jejunum is more responsive to feeding in 7- than in 26-day-old pigs. Am. J. Physiol. 270:E802-E809.

Davis, T. A., and M. L. Fiorotto. 2009. Regulation of muscle growth in neonates. Curr. Opin. Clin. Nutr. Metab. Care 12:78-85.

Davis, T. A., A. Suryawan, R. A. Orellana, M. L. Fiorotto, and D. G. Burrin. 2010. Amino acids and insulin are regulators of muscle protein synthesis in neonatal pigs. Animal 4:1790-1796.

Dickson, M. C., J. C. Saunders, and R. S. Gilmour. 1991. The ovine insulin-like growth factor-I gene: Characterization, expression and identification of a putative promoter. J. Mol. Endocrinol. 6:17-31.

Garlick, P. J., M. Fern, and V. R. Preedy. 1983. The effect of insulin infusion and food intake on muscle protein synthesis in postabsorptive rats. Biochem. J. 210:669-676.

Giraud, J., R. Leshan, Y.-H. Lee, and M. F. White. 2004. Nutrientdependent and insulin-stimulated phosphorylation of insulin receptor substrate-1 on serine 302 correlates with increased insulin signaling. J. Biol. Chem. 279:3447-3454.

Glass, D. J. 2010. PI3 kinase regulation of skeletal muscle hypertrophy and atrophy. Curr. Top. Microbiol. Immunol. 346:267-278.

Graugnard, D., P. Piantoni, M. Bionaz, L. Berger, D. Faulkner, and J. Loor. 2009. Adipogenic and energy metabolism gene networks in longissimus lumborum during rapid post-weaning growth in Angus and Angus x Simmental cattle fed high-starch or low-starch diets. BMC Genomics 10:142.

Harrington, L. S., G. M. Findlay, A. Gray, T. Tolkacheva, S. Wigfield, H. Rebholz, J. Barnett, N. R. Leslie, S. Cheng, P. R. Shepherd, I. Gout, C. P. Downes, and R. F. Lamb. 2004. The TSC1-2 tumor suppressor controls insulin-PI3K signaling via regulation of IRS proteins. J. Cell Biol. 166:213-223.

Hay, N., and N. Sonenberg. 2004. Upstream and downstream of mTOR. Genes Dev. 18:1926-1945.

Inoki, K., Y. Li, T. Xu, and K. L. Guan. 2003. Rheb GTPase is a direct target of TSC2 GAP activity and regulates mTOR signaling. Genes Dev. 17:1829-1834.

Jewell, J. L., and K. Guan. 2013. Nutrient signaling to mTOR and cell growth. Trends Biochem. Sci. 38:233-242.

Lalman, D. L., J. E. Williams, B. W. Hess, M. G. Thomas, and D. H. Keisler. 2000. Effect of dietary energy on milk production and metabolic hormones in thin, primiparous beef heifers. J. Anim. Sci. 78:530-538.

Léger, B., R. Cartoni, M. Praz, S. Lamon, O. Deriaz, A. Crettenand, C. Gobelet, P. Rohmer, M. Konzelmann, F. Luthi, and A. P. Russell. 2006. Akt signalling through GSK-3beta, mTOR and Foxo1 is involved in human skeletal muscle hypertrophy and atrophy. J. Physiol. 576:923-933.

Mieulet, V., and R. F. Lamb. 2010. Tuberous sclerosis complex: Linking cancer to metabolism. Trends Mol. Med. 16:329-335.

Naeem, A., J. K. Drackley, J. Stamey, and J. J. Loor. 2012. Role of metabolic and cellular proliferation genes in ruminal development in response to enhanced plane of nutrition in neonatal Holstein calves. J. Dairy Sci. 95:1807-1820.

Nobukuni, T., M. Joaquin, M. Roccio, S. G. Dann, S. Y. Kim, P Gulati, M. P. Byfield, J. M. Backer, F. Natt, J. L. Bos, F. J. T. Zwartkruis, and G. Thomas. 2005. Amino acids mediate mTOR/ raptor signaling through activation of class 3 phosphatidylinositol 3OH-kinase. Proc. Natl. Acad. Sci. USA 102:14238-14243.

Oddy, V. H., D. B. Lindsay, P. J. Barker, and A. J. Northrop. 1987. Effect of insulin on hind-limb and whole-body leucine and protein metabolism in fed and fasted lambs. Br. J. Nutr. 58:437-452.

Powell, M. R., and D. H. Keisler. 1995. A potential strategy for decreasing milk production in the ewe at weaning using a growth hormone release blocker. J. Anim. Sci. 73:1901-1905.

Rommel, C., S. C. Bodine, B. A. Clarke, R. Rossman, L. Nunez, T. N. Stitt, G. D. Yancopoulos, and D. J. Glass. 2001. Mediation of IGF1-induced skeletal myotube hypertrophy by $\mathrm{PI}(3) \mathrm{K} / \mathrm{Akt} / \mathrm{mTOR}$ and PI(3)K/Akt/GSK3 pathways. Nat. Cell Biol. 3:1009-1013.

Sarbassov, D. D., D. A. Guertin, S. M. Ali, and D. M. Sabatini. 2005. Phosphorylation and regulation of Akt/PKB by the rictor-mTOR complex. Science 307:1098-1101.

Stamey, J. A. 2008. Influence of starter protein content and plane of nutrition on growth and body composition of dairy calves. MS Thesis. University of Illinois, Urbana.

Stamey, J. A., N. A. Janovick, A. F. Kertz, and J. K. Drackley. 2012. Influence of starter protein content on growth of dairy calves in an enhanced early nutrition program. J. Dairy Sci. 95:3327-3336.

Stitt, T. N., D. Drujan, B. A. Clarke, F. Panaro, Y. Timofeyva, W O. Kline, M. Gonzalez, G. D. Yancopoulos, and D. J. Glass. 2004. The IGF-1/PI3K/Akt pathway prevents expression of muscle atrophy-induced ubiquitin ligases by inhibiting FOXO transcription factors. Mol. Cell 14:395-403.

Suryawan, A., and T. A. Davis. 2003. Protein-tyrosine-phosphatase 1B activation is regulated developmentally in muscle of neonatal pigs. Am. J. Physiol. Endocrinol. Metab. 284:E47-E54.

Suryawan, A., and T. A. Davis. 2005. Developmental regulation of protein kinase B activation is isoform specific in skeletal muscle of neonatal pigs. Pediatr. Res. 58:719-724.

Suryawan, A., and T. A. Davis. 2010. The abundance and activation of mTORC1 regulators in skeletal muscle of neonatal pigs are modulated by insulin, amino acids, and age. J. Appl. Physiol. 109:1448-1454.

Suryawan, A., J. Escobar, J. W. Frank, H. V. Nguyen, and T. A. Davis. 2006. Developmental regulation of the activation of signaling components leading to translation initiation in skeletal muscle of neonatal pigs. Am. J. Physiol. Endocrinol. Metab. 291:E849E859.

Suryawan, A., H. V. Nguyen, J. A. Bush, and T. A. Davis. 2001. Developmental changes in the feeding-induced activation of the insulin-signaling pathway in neonatal pigs. Am. J. Physiol. Endocrinol. Metab. 281:E908-E915.

Suryawan, A., P. M. J. O'Connor, S. R. Kimball, J. A. Bush, H. V Nguyen, L. S. Jefferson, and T. A. Davis. 2004. Amino acids do not alter the insulin-induced activation of the insulin signaling pathway in neonatal pigs. J. Nutr. 134:24-30.

Suryawan, A., R. A. Orellana, H. V. Nguyen, A. S. Jeyapalan, J. R. Fleming, and T. A. Davis. 2007. Activation by insulin and amino acids of signaling components leading to translation initiation in skeletal muscle of neonatal pigs is developmentally regulated. Am. J. Physiol. Endocrinol. Metab. 293:E1597-E1605.

Tato, I., R. Bartrons, F. Ventura, and J. L. Rosa. 2011. Amino acids activate mammalian target of rapamycin complex 2 (mTORC2) via PI3K/Akt signaling. J. Biol. Chem. 286:6128-6142.

Tee, A. R., D. C. Fingar, B. D. Manning, D. J. Kwiatkowski, L. C. Cantley, and J. Blenis. 2002. Tuberous sclerosis complex-1 and -2 gene products function together to inhibit mammalian target of 
rapamycin (mTOR)-mediated downstream signaling. Proc. Natl. Acad. Sci. USA 99:13571-13576.

Tremblay, F., S. Brûlé, S. Hee Um, Y. Li, K. Masuda, M. Roden, X. J. Sun, M. Krebs, R. D. Polakiewicz, G. Thomas, and A. Marette. 2007. Identification of IRS-1 Ser-1101 as a target of S6K1 in nutrient- and obesity-induced insulin resistance. Proc. Natl. Acad. Sci. USA 104:14056-14061.

Tremblay, F., M. Krebs, L. Dombrowski, A. Brehm, E. Bernroider, E. Roth, P. Nowotny, W. Waldhäusl, A. Marette, and M. Roden. 2005. Overactivation of S6 kinase 1 as a cause of human insulin resistance during increased amino acid availability. Diabetes 54:2674-2684.

Um, S. H., D. D'Alessio, and G. Thomas. 2006. Nutrient overload, insulin resistance, and ribosomal protein S6 kinase 1, S6K1. Cell Metab. 3:393-402.

Um, S. H., F. Frigerio, M. Watanabe, F. Picard, M. Joaquin, M. Sticker, S. Fumagalli, P. R. Allegrini, S. C. Kozma, J. Auwerx and G. Thomas. 2004. Absence of S6K1 protects against age- and diet-induced obesity while enhancing insulin sensitivity. Nature 431:200-205
Wagner, A. L., and K. L. Urschel. 2012. Developmental regulation of the activation of translation initiation factors of skeletal muscle in response to feeding in horses. Am. J. Vet. Res. 73:1241-1251.

Werner, H., M. Woloschak, M. Adamo, Z. Shen-Orr, C. T. Roberts, and D. LeRoith. 1989. Developmental regulation of the rat insulinlike growth factor I receptor gene. Proc. Natl. Acad. Sci. USA 86:7451-7455.

Wester, T. J., G. E. Lobley, L. M. Birnie, and M. A. Lomax. 2000. Insulin stimulates phenylalanine uptake across the hind limb in fed lambs. J. Nutr. 130:608-611.

Wu, A.-L., J.-H. Kim, C. Zhang, T. G. Unterman, and J. Chen. 2008. Forkhead box protein $\mathrm{O} 1$ negatively regulates skeletal myocyte differentiation through degradation of mammalian target of rapamycin pathway components. Endocrinology 149:1407-1414.

Wullschleger, S., R. Loewith, and M. N. Hall. 2006. TOR signaling in growth and metabolism. Cell 124:471-484.

Yoon, M. S., G. Du, J. M. Backer, M. A. Frohman, and J. Chen. 2011. Class III PI-3-kinase activates phospholipase D in an amino acidsensing mTORC1 pathway. J. Cell Biol. 195:435-447. 